\title{
Communicative activities to enhance oral production in the EFL classroom
}

\section{Actividades comunicativas para mejorar la producción oral en la clase de inglés como idioma extranjero}

1 Adriana Carolina Lara Velarde (iD) https://orcid.org/0000-0002-2270-6843 Universidad Nacional de Chimborazo, Facultad de Ciencias de la Educación Humanas y Tecnologías, Riobamba, Ecuador alara@unach.edu.ec

2 Jessica María Guaranga Lema (iD) https://orcid.org/0000-0002-8451-9736 Universidad Nacional de Chimborazo, Coordinación de Competencias Lingüísticas, Riobamba, Ecuador jessica.guaranga@unach.edu.ec

3 Mayra Jacqueline Iguasnia Guala (iD) https://orcid.org/0000-0003-1605-0398 Colegio de Bachillerato Chambo, Chambo, Ecuador, mayra.iguasnia@educacion.gob.ec

4 Jhon Jairo Inca Guerrero https://orcid.org/0000-0002-1296-1920 Universidad Nacional de Chimborazo, Coordinación de Competencias Lingüísticas, Riobamba, Ecuador, jhon.inca@unach.edu.ec

Artículo de Investigación Científica y Tecnológica Enviado: 30/10/2021 Revisado: 03/11/2021 Aceptado: 11/11/2021 Publicado:05/01/2022 DOI: https://doi.org/10.33262/cienciadigital.v6i1.1952

CIENCIA DIGITAL, es una Revista multidisciplinaria, Trimestral, que se publicará en soporte electrónico tiene como misión contribuir a la formación de profesionales competentes con visión humanística y crítica que sean capaces de exponer sus resultados investigativos y científicos en la misma medida que se promueva mediante su intervención cambios positivos en la sociedad. https://cienciadigital.org

La revista es editada por la Editorial Ciencia Digital (Editorial de prestigio registrada en la Cámara Ecuatoriana de Libro con No de Afiliación 663) www.celibro.org.ec 


\section{Palabras}

claves: enfoque comunicativo, actividades comunicativas, producción oral, aula de inglés como lengua extranjera

\section{Keywords:}

Communicative

Approach,

Communicative

Activities, Oral production, EFL classroom

\section{Resumen}

Introducción. La destreza de hablar se considera una de las habilidades más difíciles de desarrollar en clase al enseñar un idioma extranjero. Por lo tanto, los docentes deben buscar alternativas para mejorar la producción oral de los alumnos. En este sentido, las Actividades Comunicativas (AC) juegan un papel fundamental en la enseñanza de idiomas pues brindan oportunidades a los estudiantes para utilizar el idioma como en situaciones reales. Objetivo. El objetivo principal de esta investigación es proporcionar una descripción general de las actividades comunicativas para mejorar la producción oral en el aula de inglés como lengua extranjera. Metodología. Este artículo se basó en el enfoque cualitativo. Se realizó una investigación descriptiva-documental a través de una extensa revisión bibliográfica sobre los principios fundamentales del Enfoque Comunicativo, las actividades comunicativas, los tipos de AC y el habla. Resultados. Los resultados de las investigaciones revisadas muestran que las AC son bastante útiles para profesores y alumnos, ya que facilitan la producción oral de los alumnos mediante la interacción entre compañeros y profesores. Conclusión. Además, las actividades comunicativas motivan a los alumnos a desarrollar sus competencias lingüísticas debido a la dinámica en la que se llevan en el aula de inglés como lengua extranjera.

\section{Abstract}

Introduction. Speaking is considered one of the most difficult skills to be developed in class when teaching a foreign language. Therefore, teachers need to look for alternatives to enhance learners' oral production. In this regard, Communicative activities (CA) play a fundamental role in language teaching due to the fact they provide them with opportunities to use language as in real situations. Objective. The main goal of this research is to provide a general overview of Communicative activities to enhance oral production in the EFL classroom. Methodology. This article was based on the qualitative approach. A descriptive - documentary research was carried out through an extensive bibliographic literature review about the main principles of the Communicative Approach, communicative activities, types of CA, and speaking. Results. Results from the reviewed research investigations show that they are quite useful for teachers and learners since CA facilitate learners' oral production employing the interaction among 
classmates and teachers. Conclusion. Besides, Communicative activities encourage learners to develop their language competencies due to the dynamic in which these activities are carried out in the EFL classroom.

\section{Introduction}

Many years ago, teaching a foreign language implied learning it in a mechanical way (memorization, repetition, traditional activities, etc.). It even happens in some EFL classrooms until now. Nevertheless, the English teaching and learning process is currently different since it has a communicative purpose. Learning a foreign language involves the development of language skills. It means that EFL learners should master their communicative competencies to be able to communicate effectively with others.

Consequently, various new approaches, methods, techniques, strategies, and activities have been considered to improve language learning in EFL classrooms. Some of them have as the main purpose to encourage learners to enhance their language skills; especially, they try to motivate learners to develop their productive skills. Communicative Language Teaching is one of the approaches that promote learning a foreign language by means of different communicative activities that allow EFL students to learn it in a communicative way.

Communicative Language Teaching (CLT) emerged in the 1970s and 1980s as an innovative approach for second language teaching. It had a significant impact on second language learning since it proposes to change the traditional mechanism of teaching a foreign language. Therefore, teachers decided to implement this approach in their classrooms due to CLT's importance in developing communicative competence. It involves learners being able to use the language for real purposes. Richards (2006) argues that CLT is an approach focused on changing the traditional second language teaching process. It has communicative language goals focused on facilitating language teaching through communicative activities. In other words, CLT seeks to boost learner's ability to communicate correctly through the knowledge they receive in the classroom.

In this sense, communicative activities as part of the Communicative Approach promote language competence. The communicative activities are helpful for teachers and learners in an EFL classroom. Due to the communicative purpose of the aforementioned activities, the language learning process becomes easier for learners and teachers. Teachers can accomplish their teaching goals; furthermore, learners boost their communicative language competence. These activities promote effective language teaching since they motivate EFL students to learn a second language in an innovative and meaningful way. 
In this sense, it is necessary to mention that selecting material in order to teach English plays an important role in the language learning process. Teacher would be able in order to achieve all of the class goals if they select the appropriate material so as to enhance learners in the EFL classroom (Guerrero Chacón et al., 2019). Therefore, choosing the correct material for the EFL classroom help learners to develop and improve their language skills. Even, the skills that seems difficult for learners could become easier if the correct material or activities are selected since it is a fact that if learners receive a comprehensible input, they could improve their productive skills. Besides, it would allow teachers in order to verify and evaluate how effective the materials and activities were in the EFL classroom (Rodríguez et al., 2020).

Nowadays, the English teaching and learning process plays an essential role in society. English is one of the most important and useful languages around the world regarding communication. Therefore, it is crucial to improve the language learning process in order to facilitate learners' mastering language skills. In this context, it is vital to propose methods, techniques, strategies, etc. that can improve this learning process.

In the same way, developing productive skills can become quite difficult for some EFL learners. It is essential to seek activities that allow them to boost their speaking skill. For this reason, the current work presents some of the most important communicative activities to enhance learners' speaking skill like role play, pictures describing and, information gap.

As part of the teaching process, it is required to find the best manners to teach a foreign language. For this reason, the language learning teaching process requires the use of new ideas focused on real communication. It means that the main goal when teaching it, is to boost learners' ability to use the language they have learned in the classrooms in real environments or daily life situations. Thus, some authors have focused their attention on introducing teaching methods that can be applied in EFL classrooms.

In this regard, with the purpose to provide learners with opportunities to boost their oral production this article is developed based on bibliographical research by reviewing numerous academic sites. Along with it, various principles and tenets about Communicative activities that might be applied in the language classroom are presented.

\section{Background}

\section{Communicative Language Teaching}

AL-Garni \& Almuhammadi (2019) mention that CLT is quite effective in language teaching since it enhances learners to develop and improve their receptive and productive language skills. In contrast, traditional methods mainly focus on teaching grammar structures and vocabulary through conventional practices. Moreover, the development of 
the four language skills facilitates learner's interaction because if they master them, they will become communicative competent to interact effectively with others through a foreign language (Richards, 2006).

Learning a foreign language is more than learning and memorizing grammatical rules. It is necessary to become communicative competent. It means being someone who can actively interact with others by sharing ideas, discussing, arguing, questioning, etc. For this reason, it is crucial to carry out classes with activities that allow learners to use the learned language to face any situation from real life (Hiep, 2007). Communicative Language Teaching is an approach to teaching language with activities that support learners to acquire a foreign language in a meaningful way instead of a mechanical one. CLT fosters effective language teaching because learners are encouraged to develop their communicative competence ( $\mathrm{Ju}, 2013)$.

\section{The principles of CLT}

\section{Communication centered}

CLT carries out activities mainly focused on communication; it means using tasks that help language students to learn how to communicate effectively. Hence, teachers must consider some communicative activities for learners. Besides that, it is necessary to engage learners in the language learning process in a communicative way. According to Ma (2009), communicative activities should be applied in the EFL classroom. They encourage learners to use language for tasks like the natural environment; for instance, when working on a speaking activity, learners might interact among them to get information to solve daily problems or situations.

\section{Integrating the four language skills}

The traditional methods are focused on developing one or two language skills instead of developing all of them. On the other hand, due to the importance of the four language skills in communication, CLT tries to enhance the training of the four language skills: listening, reading, speaking, and writing. Consequently, the development and integration of all language skills facilitate communication in natural environments (Desai, 2015).

\section{Avoiding constant error correction}

CLT aims to allow learners to communicate in the target language; it means that the most important goal is learners being understood by others. Therefore, CLT does not imply correcting learners' errors all the time since it could negatively impact EFL learners. Learners sometimes become shy and lose confidence in themselves when teachers correct every EFL learners' errors. For this reason, the teacher should take notes of the errors 
committed by the whole group of students and provide feedback on them in a general way (Desai, 2015).

\section{Promoting cooperative and collaborative learning}

One of the main principles of CLT consists of promoting learner's interaction to use the foreign language in similar activities to real life. Besides, it encourages cooperative work since it is considered the best way to boost interaction among learners and teacherlearners. For this reason, when teachers assign activities in CLT classrooms, it is necessary to create workgroups or pairs of work. In this way, learners would have the opportunity to interact with their classmates, and perhaps they could learn from them when they work cooperatively (Brandl, 2008).

\section{Meaningful, comprehensible, and elaborated Input}

According to Krashen's input hypothesis (1985), input is essential when acquiring a second language. Input is the most important medium to learn vocabulary, language structures, correct pronunciation, etc., since learners can receive meaningful input for their language learning. Therefore, it is necessary to expose learners to comprehensible input; learners need to receive information that they could find difficult to produce, but they can comprehend it. That is the reason why CLT creates an environment in which learners could receive valuable and rich input for their language learning process (Alahmadi, 2019).

\section{Focus on form}

CLT approach is entirely focused on boosting the learners' ability to communicate effectively in the target language. Sometimes, some errors are ignored since the most important to CLT is to be understood by others and understand others; nevertheless, it is necessary to consider how language is produced. In regards to the form of the language; it involves the structures or grammar since communication cannot take place if language is not correctly used (Ma, 2009). Hence, it is necessary to provide learners enough grammar input through communicative activities that help them learn it in a communicative way. It refers to encouraging the learning of grammar to be able to use it when learners need to communicate (Wong \& Barrea-Marlys, 2012).

\section{Communicative competence}

Communicative Language Teaching encourages language learners' communicative competence improvement. This process allows students to become authentic communicators. Canale \& Swain (1980) defined communicative competence as "underlying systems of knowledge and skill required for communication". According to Richards (2006), language learners must train their communicative competencies to 
achieve a good proficiency in a foreign language and communicate effectively in any context. Communicative competence consists of four communicative components:

\section{Linguistic Competence}

The production of a language implies the correct use of grammar, vocabulary, and pronunciation. The characteristics mentioned above of the use of language have a close relationship with language production accurately and fluently. Chomsky (1965), argues that linguistic competence involves the knowledge of grammar since it is part of being excellent speakers and listeners. Moreover, it refers to the production of understandable language; it mainly regards the proper development of speaking employing the use of the appropriate grammatical rules and the correct vocabulary (Salazar, 2015).

\section{Socio Linguistic Competence}

Language learners must be able to use the appropriate language according to the context where they use it. Socio-Linguistic competence refers to its use depending on the audience to whom the speaker is interacting. In other words, it is using language depending on the social and cultural background; therefore, it is necessary to take into account some factors like age, gender, status, etc. (Mede \& Dikilitaş, 2015). Furthermore, Socio-linguistic competence helps language learners to avoid misunderstanding or social issues as well. Nevertheless, mastering socio-linguistic competence could become challenging for language learners due to the variation of social, cultural, and pragmatic elements. It refers to something correct in one context that could be wrong for another (Ya, 2016).

\section{Discourse Competence}

Discourse competence regards the ability to understand and produce extended speech and written features which assists connectedness and cohesion (Kaplan \& Knutson, 1993). Discourse competence lets learners use language with coherence and cohesion when it is produced in a written way. On the other hand, it is also mandatory that language learners coherently produce oral language; it means that they have to be able to organize their ideas appropriately; besides, they would be able to connect their ideas to facilitate communication (Januin \& Stephen, 2015).

\section{Strategic Competence}

Strategic competence involves the set of strategies used by language learners to compensate for some gaps in the use of a foreign language (Canale \& Swain, 1980). It regards the EFL learners' ability to communicate successfully employing active discussion. Therefore, it is necessary to mention that strategic competence is not related to language proficiency since some learners could have a lot of knowledge about any 
foreign language; nevertheless, they cannot interact effectively with others (Negoescu et al., 2019). Eventually, strategic competence has a close relation to the ability to maintain an active conversation.

\section{Communicative activities in the EFL classroom}

Communicative activities allow learners to use the language for fundamental purposes; they involve authentic communication (Stern, 1992); (Suárez Cabrera et al., 2020). These activities focus their objectives on the meaningful use of a foreign language to develop the assigned activities. Moreover, they are centered on students' interests and necessities instead of the teacher. It is necessary to consider that the development of these activities requires the interaction student-student. Therefore, teacher intervention is less common than in traditional activities (Ellis, 2010).

It is mandatory to select the correct classroom tasks; for instance, it would be advisable to assign communicative activities according to the level of EFL learners to avoid any problem when they develop them. Furthermore, teachers must be conscious that selecting these kinds of activities demands to bear in mind a specific criterion when performing it. Ochoa et al. (2016) claim that communicative activities must enhance the use of language focused on the meaning.

\section{Role play}

Role play is a technique commonly used in the EFL classroom to boost learners' confidence and motivation to interact with others. It creates real contexts or scenarios in which it is necessary to communicate effectively with their classmates (Huff, 2012). In addition, role-play allows EFL learners to participate actively in the EFL classroom since they feel more confident about themselves. Aliakbari \& Jamalvandi (2010) define roleplay as an effective technique to improve speaking skills since it encourages learners to practice the language in the classroom as much as possible.

\section{Picture Description}

Describing a picture is a communicative activity that consists of producing language to describe visual material. Picture describing is one of the most valuable techniques to boost speaking skill in the EFL classroom and increase learners' involvement in the language learning process (Brown, 2007). In addition, this technique helps learners to memorize and use new vocabulary or grammatical structures. Due to the necessity of using language for real situations, describing picture is an essential technique that provides learners the opportunity to put in practice the knowledge they learn in the EFL classroom (Lavalle \& Briesmaster, 2017).

\section{Information - Gap}


Information - Gap refers to the set of activities used to motivate learners to use the language when they must accomplish the goal of a task. It enhances the oral interaction among learners because they need to communicate with each other to share ideas, opinions, suggestions, comments, etc., to complete the information of any assigned activity (Harmer \& Surguine, 1987). Information gap becomes for learners one of the most useful and interesting activities since they consider it is quite practical to use language in real environments; moreover, it helps them to successfully complete a task in the EFL classroom (Neira, 2019).

\section{Sharing Personal Experiences}

As it is known, the main goal of learning a language is to use it as in a real context. In other words, to be able to interact with others by expressing ideas, thoughts, feelings (Sevilla-Pavón \& Haba-Osca, s.f). In this regard, Sharing Personal Experiences is an authentic Communicative Activity that allows learners to share their insight about a moral or dilemma that could be presented to them (Richards 2006).

\section{Debates}

Debates are considered a valuable communicative activity because they promote interaction in the classroom. Debates promote an enjoyable learning environment among learners due to the fact they keep them active and involved in the activity while they are providing their opinions of the topic being discussed (Firmansyah \& Valatansa, 2019). Learners not only express what they prepared for the class but also can use language spontaneously when agreeing or contradicting someone's ideas (Pradana, 2017). Furthermore, debates not only foster the development of language use but also critical thinking skills. Students have to know how to use the language appropriately and the content to be discussed as well (Elmiyati, 2019). In this sense, debates involve reasoning when students try to deliver their arguments. Therefore, it becomes challenging and beneficial for students' oral production (Syamdianita \& Maharia, 2020).

\section{Problem - Solving}

Problem - solving introduces students to a topic that requires finding a solution, something to be solved. It involves two essential processes: to develop critical thinking skills and to facilitate language use (Constantine the Philosopher University in Nitra \& Pavlikova, 2019). In this regard, Larsen-Freeman (2000) point out that this activity is part of the main components of the Communicative Approach to foster language use and deep into details to seek an adequate solution. Moreover, problem- solving tasks introduce students to an issue to be solved. To do so, they have to interact in the language classroom with their classmates to find a solution (Oradee, 2013). Consequently, by giving students 
a problem, it becomes an opportunity for them to practice speaking due to the fact they will provide ideas, make suggestions, analyze the issues to be solved.

\section{Speaking skill}

Speaking is considered a productive skill that allows learners to be able to interact with people around them, to express their opinions, feelings, and thoughts. This skill provides students with opportunities not only for communicating but for exchanging information among people (Richard, 2006). When learning a foreign language, speaking plays a crucial role because it is part of a learner's language proficiency and permits them to negotiate meaning with the ones around them (Rao,2019). In this regard Wicaksono et al. (2016) point out that speaking involves a complex process of building and sharing meaning by means of using language as the medium of communication.

In the teaching and learning process, speaking is one of the skills that are more practiced during class time. Speaking is considered a prominent language skill owing to the necessity that learners have to communicate and it becomes one of the primary goals of language teaching (Fandana et al., s.f.) Therefore, teachers look for activities that will help them boost their students' oral production. In this context, it is essential that the language that students use to communicate be as real as possible.

\section{Speaking Subskills}

Speaking is considered the most outstanding skill in the language classroom due to the fact learners always use it as their medium of communication (Masuram \& Sripada, 2020). In this sense, speaking aims to provide learners with the capacity of expressing what they think, to interact with the people that surround them, to convey meaning, to be able to use language for communicative purposes (Maulidar et al., 2019).

\section{Pronunciation}

Pronunciation is an essential component of speaking development, it is the ability that learners have to utter a word appropriately (Pourhosein, 2012). Pronunciation involves learners producing intelligible messages by taking into consideration many factors in the production i.e. phonemes, stress, rhythm, and intonation (Pardede, 2018). It is also considered as the production of English sounds when communicating a message (Paulston \& Burder, 1976). In this sense, pronunciation becomes a core component in speaking because for a person to be understood, he/she needs to articulate the words adequately (Handayani,2017. Therefore, it has also become an essential element in foreign language teaching (Tlazalo \& Basurto, 2014). In this regard, teachers should work with activities that contribute to the development of this speaking sub-skill for instance by practicing sounds, syllables, stress, and intonation (Gilakjani et al., 2011). 
Moreover Priya \& NS (2020), suggest that the teaching of phonetics when learning another language can make students develop pronunciation awareness when speaking.

\section{Grammar}

Grammar is considered an important component in language teaching (Navaz \& Sama, 2017). It is known as the structured organization of words in a language when producing utterances (Meenadevi, 2017). According to Saaristo (2015), grammar is the core component when learning a foreign language because it allows speakers to connect words, ideas, and phrases coherently. When speaking it involves learners in using language appropriately. In other words, to use grammar patterns in a correct way (Azlina et al., 2015). Furthermore, grammar plays a crucial role in any language due to the fact if a speaker communicates a message correctly everything will make sense both for foreign and native speakers (Rao, 2019).

\section{Vocabulary}

Vocabulary is another important component of language learning (Cameron, 2001). When someone wants to express something, it is necessary to have at least a basic knowledge of words. According to Nunan (1991), a successful language learner will have a high level of vocabulary knowledge otherwise it will be difficult to be understood in a foreign language context. Lexical knowledge is an essential element when developing language competence (Alqahtani, 2015). Moreover, the mastery of vocabulary contributes to the development of language skills. All of them are related to each other (Asyiah, 2017).

Vocabulary has been acknowledged as one of the speaking sub-skills due to the fact it permits learners to express their opinions, feelings, and thoughts. In this regard, the teaching of vocabulary in the language classroom is essential. Therefore, its learning should be promoted in the language classroom by means of using different techniques to make this process significant (Alqahtani, 2015).

\section{Fluency}

Fluency as part of the speaking sub-skills requires students to use the language smoothly and without any kind of rehearsal (Masuram \& Sripada, 2020). It is closely related to the idea of communication (Albino, 2017). A fluent person may have already developed his/her communicative competence. In other words, this person will be able to use language without hesitation when having a conversation (Samifanni, 2020; Oviedo \& Mena, 2021). Additionally, when a speaker is fluent, this person can use the language patterns appropriately. 


\section{Intonation}

Intonation is considered an important factor in speaking. It is the changes of pitch people make in their speech when communicating a message or interacting with the ones who surround them (Kenworthy,1987). When people are communicating, intonation provides information about their attitude and the purpose of speaking (Yangklang, 2013). In this regard, Intonation contributes to distinguishing the different types of sentences, for instance, statements, imperatives, questions, declaratives, exclamative, etc. It allows the audience to understand what a person intends to express (Zulfugarova, 2018).

\section{Methodology}

This article was based on the qualitative approach. A descriptive - documentary research was carried out through an extensive bibliographic literature review about Communicative Activities and oral production.

First, once the problem of this research was stated, the bibliographic method was utilized by searching the information using various Search Equation as Communicative activities AND speaking, Communicative Competence OR Language competence, Communicative Language Teaching AND principles, "Communicative activities" AND "Language Learning", "Communicative tasks" " Solving problems" AND "Critical Thinking", Speaking AND sub-skills to gather the information required for this investigation. As it is shown in figure 1, these articles were taken from both primary and secondary sources from Research Articles, Articles from Scientific Journals, Books, and papers.

Figure 1. Type of consulted material. Academic sources

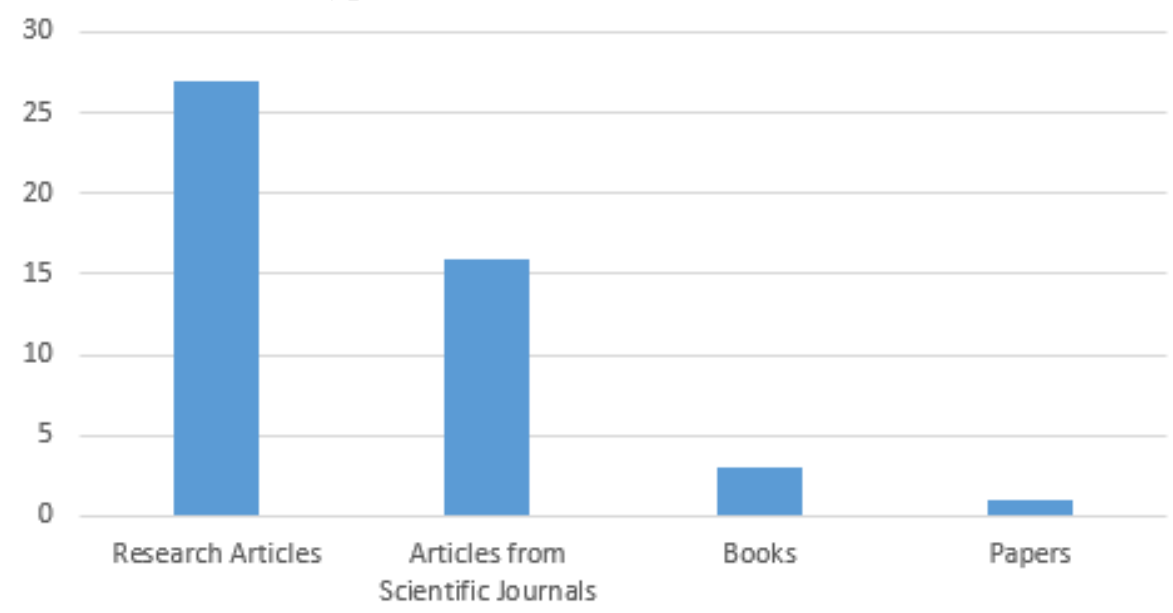

Done by: The author.

These articles were taken from numerous search engines such as Google scholar, Scielo, semantic scholar, Research gate, etc. (See figure 2). 
Figure 2. Search engines used in the research. Online repositories

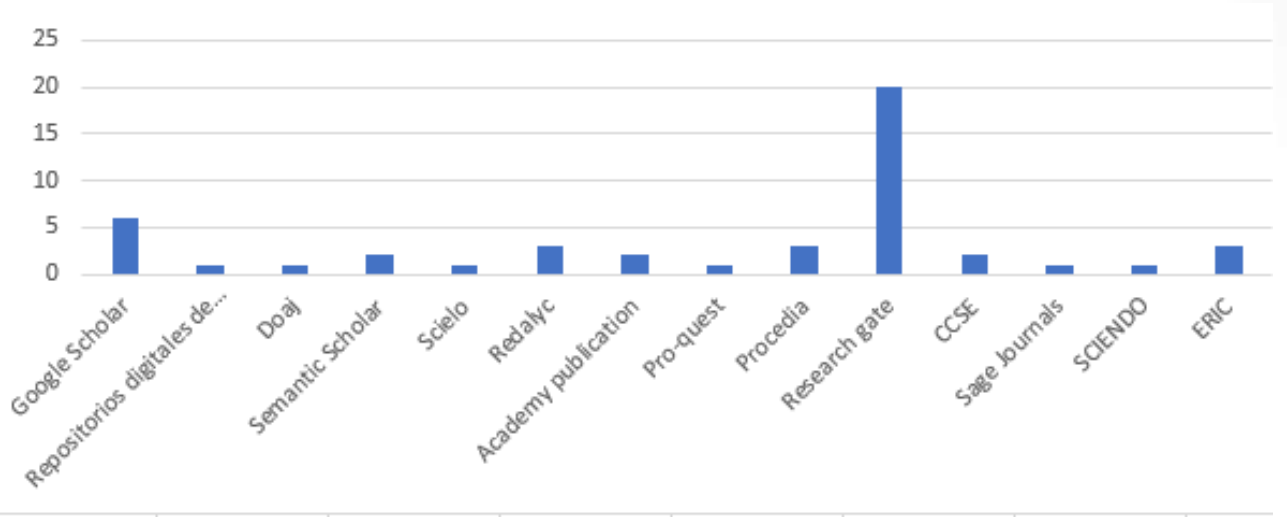

Done by: The author.

Second, the collected information was organized and categorized logically bearing in mind the search criteria. Then 47 scientific articles were selected after an extensive review of the primary and secondary sources. Third, with this information, the state of art was created taking into consideration relevant aspects of the topic.

\section{Results and Discussion}

Results from previous studies demonstrate that Communicative Activities CA enhance the development of the oral production of students in the English Foreign Language Classroom. The use of CA such as Role play, Picture Describing, Information - Gap, Sharing Personal Experiences, Debates, and Problem-solving contributes to developing the communicative competence of learners. Moreover, these activities get students engaged in using the language when communicating among them. To perform these tasks, students need to use the language to carry out them. Most CA are based on real- life situations. In this regard, students not only practice communicating for the task but for daily life issues.

The great majority of scientific articles that were used as a basis for this research show a positive impact on students' performance. For instance, information gap activities are considered as an effective Communicative Activity when developing learner's ability to speak due to the fact students need to fill the gap. Therefore, they have to use the language for asking questions, exchanging ideas (Neira, 2019).

As stated above, Communicative activities provide benefits in the language classroom. They are effective strategies when developing learner's autonomy while speaking in English. They provide students with opportunities to use the language spontaneously. In addition, they can negotiate meaning, to promote fluency and boost motivation in the EFL classroom (Elmiyati, 2019). 


\section{Conclusions}

- Speaking is considered one of the most predominant skills in language learning. In this regard, researchers have carried out various studies to identify which methods, strategies, and techniques help learners develop their ability to communicate. In this context, the Communicative Approach encompasses a great variety of activities that aim to develop learners' autonomy when using English to interact with people around them. Therefore, Communicative Activities such as Role play, Picture Describing, Information - Gap, Sharing Personal Experiences, Debates, and Problem-solving have become an essential tool when boosting students' oral production.

- It is of paramount importance to highlight the benefits that Communicative Activities offer to language learners. As an illustration, CA make students get engaged in using the language due to the fact each activity has a purpose for using it. Consequently, there is a high impact on the ability to use the language fluently. Furthermore, they increase learners' motivation and facilitates language use as in real life. CA allow students to practice language that is commonly used in daily life.

- It is crucial to remark that this research provides a general overview of what Communicative Activities could be implemented in foreign language teaching to support learners in developing their ability to communicate. However, it is worth mentioning that several pedagogical implications need to be considered when implementing CA activities in the classroom. Further research should be conducted about the process that has to be followed when implementing each Communicative Activities.

\section{Bibliographical references.}

Alahmadi, N. S. (2019). The Role of Input in Second Language Acquisition: An Overview of Four Theories. Bulletin of Advanced English Studies, 3(2). https://doi.org/10.31559/baes2019.3.2.1

Albino, G. (2017). Improving Speaking Fluency in a Task-Based Language Teaching Approach: The Case of EFL Learners at PUNIV-Cazenga. SAGE Open, 7(2), 215824401769107. https://doi.org/10.1177/2158244017691077

AL-Garni, S. A., \& Almuhammadi, A. H. (2019). The Effect of Using Communicative Language Teaching Activities on EFL Students' Speaking Skills at the University $\begin{array}{llll}\text { of Jeddah. English Language Teaching, } & \text { 12(6), }\end{array}$ https://doi.org/10.5539/elt.v12n6p72 
Aliakbari, M., \& Jamalvandi, B. (2010). The Impact of «Role Play» on Fostering EFL Learners' Speaking Ability: A Task-Based Approach. Association of Applied Linguistics, 14, 15.

Alahmadi, N. S. (2019). The Role of Input in Second Language Acquisition: An Overview of Four Theories. Bulletin of Advanced English Studies, 3(2). https://doi.org/10.31559/baes2019.3.2.1

Albino, G. (2017). Improving Speaking Fluency in a Task-Based Language Teaching Approach: The Case of EFL Learners at PUNIV-Cazenga. SAGE Open, 7(2), 215824401769107. https://doi.org/10.1177/2158244017691077

AL-Garni, S. A., \& Almuhammadi, A. H. (2019). The Effect of Using Communicative Language Teaching Activities on EFL Students' Speaking Skills at the University of Jeddah. English Language Teaching, 12(6), 72. https://doi.org/10.5539/elt.v12n6p72

Aliakbari, M., \& Jamalvandi, B. (2010). The Impact of «Role Play» on Fostering EFL Learners' Speaking Ability: A Task-Based Approach. Association of Applied Linguistics, 14, 15.

Alqahtani, M. (2015). The importance of vocabulary in language learning and how to be taught. International Journal of Teaching and Education, III (3), 21-34. https://doi.org/10.20472/TE.2015.3.3.002

Asyiah, D. N. (2017). THE VOCABULARY TEACHING AND VOCABULARY LEARNING: PERCEPTION, STRATEGIES, AND INFLUENCES ON STUDENTS' VOCABULARY MASTERY. Journal Bahasa Lingua Scientia, 9(2), 293-318. https://doi.org/10.21274/ls.2017.9.2.293-318

Azlina Kurniati Kurniati, Eliwarti Eliwarti, \& Novitri Novitri. (2015). A Study on the Speaking Ability of the Second Year Students of Smk Telkom Pekanbaru. Journal Online Mahasiswa Fakultas Keguruan dan Ilmu Pendidikan Universitas Riau, 2(2), 1-14.

Brandl, K. (2008). Principles of Communicative Language Teaching and Task-Based Instruction. Communicative Language Teaching in Action: Putting Principles to Work (pp. 1-23). Pearson Prentince Hall.

Brown, D. (2007). Principles of language learning \& teaching (5ta ed.). Pearson: Longman.

Cameron, L. (2001). Teaching languages to young learners. Cambridge: Cambridge University Press. 
Canale, M., \& Swain, M. (1980). Theoretical Bases of Communicative Approaches to Second Language Teaching and Testing. 42, 47. https://doi.org/10.1093/applin/amaa037

Chomsky, N. (1965). Aspects of the Theory of Syntax (Cambridge, Massachusetts, Vol. 1). The M.IT. Press.

Constantine the Philosopher University in Nitra, \& Pavlikova, K. (2019). Use of monologues, games and problem-solving activities for development of speaking skills. Educational Role of Language Journal, 1(1), 83-92. https://doi.org/10.36534/erlj.2019.01.08

Desai, A. A. (2015). Characteristics and Principles of Communicative Language Teaching. 3(7), 3.

Ellis, R. (2010). The Study of Second Language Acquisition. System, 38(1), 146-148. https://doi.org/10.1016/j.system.2009.11.003

Elmiyati, E. (2019). Improving Students Speaking Ability Through Debate in The Classroom (A Case Study for Students at Second Years Students of SMAN 3 Kota Bima in Academic Year 2017/2018). International Journal of Multicultural and $\begin{array}{lll}\text { Multireligious } & \text { Understanding, }\end{array}$ https://doi.org/10.18415/ijmmu.v6i1.561

Fandana, R., Yufrizal, H., \& Simbolon, R. (s. f.). INCREASING STUDENTS' SPEAKING ABILITY THROUGH PROBLEM SOLVING. 14.

Firmansyah, D., \& Valatansa Vegian, E. E. (2019). Improving the Students' Speaking Skill through Debate Technique. PROJECT (Professional Journal of English Education), 2(6), 891. https://doi.org/10.22460/project.v2i6.p891-895

Gilakjani, A., Ahmadi, S., \& Ahmadi, M. (2011). Why is Pronunciation So Difficult to Learn? English Language Teaching, 4(3), p74. https://doi.org/10.5539/elt.v4n3p74

Guerrero Chacón, K. E., Vallejo Barreno, C. F., \& Caicedo Valencia, M. S. (2019). Estrategias didácticas para la enseñanza del inglés en educación media general. Ciencia Digital, $3(4.2)$, $25-42$. https://doi.org/10.33262/cienciadigital.v3i4.2.1001

Harmer, J., \& Surguine, H. (1987). Coast to Coast.

Handayani, I., \& Rahmawati, E. (2017). Students' Speaking Anxiety at English Classroom in Agroecotechnology Department of Agricultural Faculty Untirta (A 
Descriptive Study in AgroEcoTechnology Classroom, Untirta). Journal of English Language Studies, 2(2).

Hiep, P. H. (2007). Communicative language teaching: Unity within diversity. ELT Journal, 61(3), 193-201. https://doi.org/10.1093/elt/ccm026

Huff, C. (2012). Action research on using role play activity in an adult ESL level one class. 490.

Januin, J., \& Stephen, J. (2015). Exploring Discourse Competence Elements in EAP Class Presentations through Document and Ethnographic Analyses. Procedia - Social and Behavioral Sciences, 208, 157-166. https://doi.org/10.1016/j.sbspro.2015.11.192

Ju, F. (2013). Communicative Language Teaching (CLT): A Critical and Comparative Perspective. Theory and Practice in Language Studies, 3(9), 1579-1583. https://doi.org/10.4304/tpls.3.9.1579-1583

Kaplan \& Knutson. (1993). The role of materials in the language classroom: Finding the balance. TESOL in Context, 5(1), 25-33.

Krashen, S. D. (1985). Cha. 1: «The input Hypothesis. Issues and Implications». Theory of Second Language Acquisition (Vol. 1, pp. 1-32). Longman Group UK Ltd.

Kenworthy, J. (1987). Teaching English pronunciation.

Larsen-Freeman, D. (2000). Techniques and principles in language teaching. Oxford University.

Lavalle, P. I., \& Briesmaster, M. (2017). The study of the Use of Picture Descriptions in Enhancing Communication Skills among the 8th-Grade Students-Learners of English as a Foreign Language. 18.

Ma, T. (2009). On Communicative Language Teaching-Theoretical Foundations and Principles. Asian Social Science, 5(4), p40. https://doi.org/10.5539/ass.v5n4p40

Masuram, J., \& Sripada, P. N. (2020). DEVELOPING SPEAKING SKILLS THROUGH TASK-BASED MATERIALS. Procedia Computer Science, 172, 60-65. https://doi.org/10.1016/j.procs.2020.05.009

Maulidar, K., Gani, S. A., \& Samad, I. A. (2019). TEACHER'S STRATEGIES IN TEACHING SPEAKING FOR CADETS. I. A., 15. 
Mede, E., \& Dikilitaş, K. (2015). Teaching and Learning Sociolinguistic Competence: Teachers' Critical Perceptions. Participatory Educational Research, 2(3), 14-31. https://doi.org/10.17275/per.15.29.2.3

Meenadevi, D. M. (2017). Strategies in Teaching English Grammar. 6.

Navaz, A., \& Sama, F. (2017). TEACHING GRAMMAR IN THE ENGLISH LANGUAGE CLASSROOM: PERCEPTIONS AND PRACTICES OF STUDENTS AND TEACHERS IN THE AMPARA DISTRICT. 16.

Negoescu, A. G., Boştină-Bratu, S., \& Morar, L.-L. (2019). Strategic and Social Competences in the Foreign Language Class. Scientific Bulletin, 24(1), 61-66. https://doi.org/10.2478/bsaft-2019-0007

Neira, R. A. O. (2019). The Impact of Information Gap Activities on Young EFL Learners' Oral Fluency. . ISSN, 21(2), 13.

Nunan, D. (1991). Language teaching methodology (Vol. 192). New York: prentice hall.

Ochoa, C., Cabrera, P., Quiñónez, A., Castillo, L., \& González, P. (2016). The Effect of Communicative Activities on EFL Learners' Motivation: A Case of Students in the Amazon Region of Ecuador. Colombian Applied Linguistics Journal, 18(2), 39. https://doi.org/10.14483/calj.v18n2.10018

Oradee, T. (2013). Developing Speaking Skills Using Three Communicative Activities (Discussion, Problem-Solving, and Role-Playing). International Journal of Social Science and Humanity, 533-535. https://doi.org/10.7763/IJSSH.2012.V2.164

Oviedo Guado, N. G., \& Mena Mayorga, J. I. (2021). Communicative language teaching approach in the development of speaking skill. Ciencia Digital, 5(4), 6-26. https://doi.org/10.33262/cienciadigital.v5i4.1865

Pardede, P. (2018). Improving EFL Students' English Pronunciation by Using the Explicit Teaching Approach. JET (Journal of English Teaching), 4(3), 143. https://doi.org/10.33541/jet.v4i3.852

Paulston, C. B., \& Bruder, M. N. (1976). Teaching English as a Second Language. Techniques and Procedures.

Pourhosein Gilakjani, A. (2012). The Significance of Pronunciation in English Language Teaching. English Language Teaching, 5(4), p96. https://doi.org/10.5539/elt.v5n4p96

Pradana, S. A. (2017). Using debate to enhance students' speaking ability as their character building. English Education: Journal Tadris Bahasa Inggris, 10(1), 149-163. 
Priya, M. L. S., \& NS, P. K. (2020). Teaching phonetics to enhance pronunciation in an ESL classroom. Journal of Critical Reviews, 7(2), 669-672.

\section{Rao, P. S. (2019). THE ROLE OF GRAMMAR IN ENGLISH LANGUAGE TEACHING (ELT) TECHNIQUES. 4, 12.}

Richards, J. (2006). Explorations in corpus linguistics. Cambridge University Press.

Rodríguez Durán, M. E., Sandra Paulina, P. P., \& Moyota Amaguaya, P. P. (2020). Evaluación alternativa en la producción oral de estudiantes de Nivel A2. Ciencia Digital, 4(1), 34-53. https://doi.org/10.33262/cienciadigital.v4i1.1062

Saaristo, P. (2015). Grammar is the heart of language: grammar and its role in language learning among Finnish university students. Voices of pedagogical developmentExpanding, enhancing and exploring higher education language learning, 279-318.

Salazar Obeso, W. (2015). Exploring Communicative Competence Development in an EFLT Classroom at Cursos Libres. Zona Próxima, 23, 88-103. https://doi.org/10.14482/zp.23.7214

Samifanni, F. (2020). The Fluency Way: A Functional Method for Oral Communication. English Language Teaching, 13(3), 100. https://doi.org/10.5539/elt.v13n3p100

Sevilla-Pavón, A., \& Haba-Osca, J. (s. f.). "Learning from real life and not books": A gamified approach to Business English task design in transatlantic telecollaboration. 27.

Stern, H. H. (1992). Language Learning Strategies Among EFL/ESL Learners: A Review of Literature. International Journal of Humanities and Social Science, 2(5), 8.

Suárez Cabrera, S. M., Molina Mazón, R. P., \& Abarca García, S. L. (2020). Estrategias de interacción en el desarrollo de la destreza productiva del habla del idioma inglés. Ciencia Digital, $4(1), \quad 126-141$. https://doi.org/10.33262/cienciadigital.v4i1.1077

Syamdianita, \& Maharia, A. C. (2020). Developing Speaking Skill Through Debating: Undergraduate EFL Students' Perception. Proceedings of the 2nd Educational Sciences International Conference (ESIC 2019). 2nd Educational Sciences International Conference (ESIC 2019), Samarinda, Indonesia. https://doi.org/10.2991/assehr.k.200417.006

Tlazalo Tejeda, A. C., \& Basurto Santos, N. M. (2014). Pronunciation Instruction and Students' Practice to Develop Their Confidence in EFL Oral Skills. PROFILE 


\section{www.cienciadigital.org}

Issues in Teachers' Professional Development, 16(2), 151-170. https://doi.org/10.15446/profile.v16n2.46146

Wicaksono, B. H., Pd, S., \& Ed, M. (2016). TEACHER'S TALK ROLE IN TEACHING SPEAKING. 9.

Wong, C. C. Y., \& Barrea-Marlys, M. (2012). The Role of Grammar in Communicative Language Teaching: An Exploration of Second Language Teachers' Perceptions and Classroom Practices. 9(1), 15.

Ya, L. (2016). A study of language teaching from a sociolinguistic perspective of communicative competence. $4,80-86$.

Yangklang, W. (2013). Improving English Stress and Intonation Pronunciation of the First Year Students of Nakhon Ratchasima Rajabhat University through an eLearning. Procedia - Social and Behavioral Sciences, 91, 444-452. https://doi.org/10.1016/j.sbspro.2013.08.442

Zulfugarova, R. (2018). The Function of Intonation in the English Language. Web of Scholar, 7(6), 18-21.

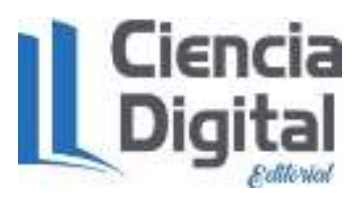


El artículo que se publica es de exclusiva responsabilidad de los autores y no necesariamente reflejan el pensamiento de la Revista Ciencia Digital.

\section{Ciencia \\ LDigital}

El artículo queda en propiedad de la revista y, por tanto, su publicación parcial y/o total en otro medio tiene que ser autorizado por el director de la Revista Ciencia Digital.
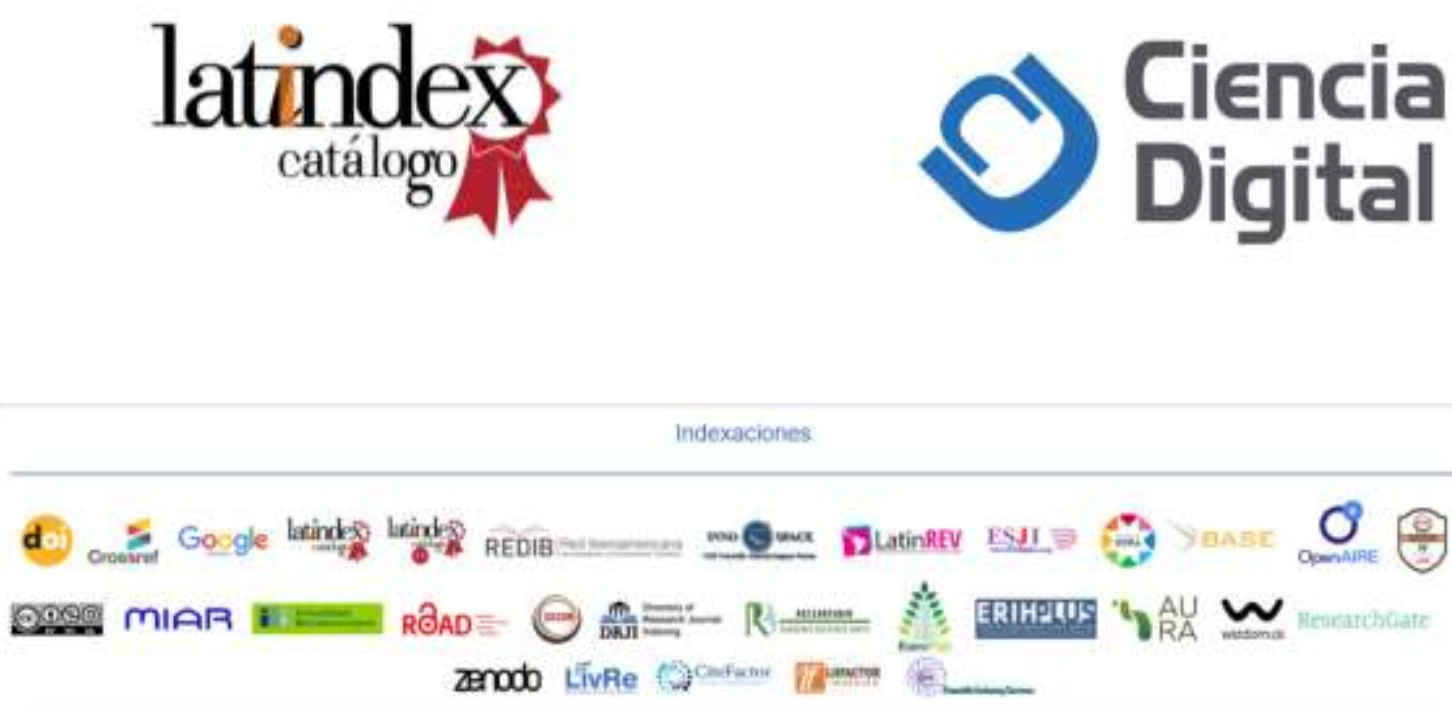